(An Epistemological Hierarchy?); autora interesują tu także relacje między wiarą, rozumem i opinią (Faith, Reason, and Opinion); chociaż pierwsza z nich jest najwznioślejsza w poznawaniu prawdy, jednak każda $z$ nich ma swe kompetencje i ograniczenia; ostatniej do jej autentyczności potrzebny jest dodatkowo świadectwo tradycji i autorytet Kościoła.

$\mathrm{Na}$ tym tle można dopiero zrozumieć pozorne sprzeczności związane w bernardyńską epistemologią (Inconsistency and Order), sprzeczności, które odbiły się na znanym $\mathrm{z}$ historii słynnym casusie Abelarda. Sprzeczności dotyczą pogodzenia pracy duszpasterskiej z nauczaniem scholastycznym, niebezpieczeństw wynikających ze światowej próżnej wiedzy filozoficznej i ciekawości. Bernard znany ze swego pisarstwa, posłuszny prośbom i nakazom przełożonych czy przyjaciól, a także kierujący się umiłowaniem prawdy, przedłożył swój system, który mimo braku ścisłych scholastycznych norm uchodził za ówczesną ostoję prawowierności nauczania teologicznego (The Chimaera Revisted). Na tle tych ostatnich rozdziałów (VII-VIII) autor wyjaśnia w końcu dość enigmatyczny casus potępienia błędnego nauczania Abelarda (The Abelard Affair). Sommerfeldt twierdzi, ze błędność jego nauki według Bernarda leżała w stosowanej przez filozofa metodzie badania prawd wiary czystą logiką rozumu, która ma swoje granice, i stąd wynikały jego błędy dogmatyczne. Podobny przypadek odzwierciedlał później casus biskupa Gilberta de la Porée, który powtarzał niektóre tezy Abelarda, ale je zaraz odwołał.

Książka profesora Sommerfeldta jest rzeczywiście ciekawa i prosta w czytaniu. Autor $z$ łatwością prowadzi czytelnika po szlakach teologii monastycznej Bernarda z Clairvaux, uwypuklając aspekt epistemologiczny, dotąd specjalnie nie poruszany przez badaczy. Tym samym rozjaśnia wiele niejasnych stron tego nauczania i związane $z$ nimi wydarzenia, dając to dla zrozumienia spornych i sprzecznych kwestii. Świetnym przykładem jest tu właśnie casus Abelarda i Gilberta, dla wytłumaczenia którego zdaje się powstała ta publikacja, zamykając niejako długoletnie spory na ten temat. Jest ona warta polecenia dla każdego, kto chce zrozumieć specyfikę dwunastowiecznej teologii monastycznej, której Bernard był wielkim motorem, by widzieć z jej perspektywy rozwiązania ówczesnych problemów.

$$
\text { Ks. Ryszard Groń - Chicago USA }
$$

\title{
Ks. Jan ŻELAZNY, Biskup Ojcem. Zarys eklezjologii syryjskiej na podstawie „Konstytucji Apostolskich”, Kraków 2006, ss. 296.
}

Z uznaniem należy przyjąć studium ks. dra Jana Żelaznego dające zarys eklezjologii syryjskiej i ukazujące biskupa jako ojca w świetle Konstytucji Apostolskich. Praca poza wstępem i zakończeniem składa się z pięciu rozdzia- 
lów. We wstępie Autor określa cel pracy: pragnie w niej wyjaśnić pojmowanie Kościoła jako domu w dokumencie, będącym syntezą myśli obecnej w Kościele IV wieku na terenie rzymskiej Syrii. Stąd też czyni rozróżnienie dwóch określeń: Kościół jako dom i Kościół domowy. Pierwszy odnosi się do całego Kościoła, drugi do chrześcijańskiej rodziny jako cząstki Kościoła - mikrokościoła. $\mathrm{Z}$ uwagi na szerokość podejmowanych w pracy zagadnień, dopiero w rozdziale pierwszym Autor dysertacji zarysowuje status quaestionis oraz precyzuje używane $w$ ramach pracy terminy. Jako pierwszy na gruncie polskim podejmuje charakterystykę samych Konstytucji - pod względem języka, jak i zagadnień teologicznych poruszonych w tym dokumencie.

Posługując się analizą historyczno-filologiczną (tak mówi o metodzie swej pracy sam jej Autor), w praktyce jednak korzystając również z opracowań, określił miejsce i rolę rodziny $\mathrm{w}$ ówczesnym społeczeństwie rzymskim. Bez przywołania bowiem różnicy pomiędzy funkcjonowaniem domu w starożytności a dziś, trudno byłoby zrozumieć tekst Konstytucji. Rozdział pierwszy (s. 1362) kończy krótka charakterystyka kościelnego środowiska antiocheńskiego z końca IV wieku (ciekawa, bo nie ma analogicznej w języku polskim). Szkoda, że ks. Żelazny pisząc o znaczeniu słów służących w tym czasie na określenie rodziny ani razu nie powołał się na publikacje zawarte w „Vox Patrum" 5 (1985) z. 8-9, w całości poświęconym małżeństwu i rodzinie w chrześcijaństwie starożytnym, gdzie autor pierwszego artykułu zajmuje się starożytnq rodzinq grecka i rzymska (ss. 29-50). Ks. Żelazny oparł się na materiale słownikowym dla ustalenia możliwych konotacji symbolicznych, używanych w Konstytucjach Apostolskich wyrazów: „ojciec" i „dom”. Na s. 52 pisze: „Słowo ojciec w swoim semickim wymiarze jako abba czy też indoeuropejskim $\pi \alpha \tau \eta \dot{\varrho}$, już w swoim filologicznym źródłosłowie oznacza w obu kulturach zarówno męża, ojca dzieci, jak i głowę domu". Jest to wyrażenie nieprecyzyjne, lepiej byłoby użyć wyrażenia: wywodzące się z indoeuropejskiego greckie $\pi \alpha \tau \eta$, bo według opinii językoznawców wyrazy „pater” i ,potestas” podobnie jak sanskryckie „pi-

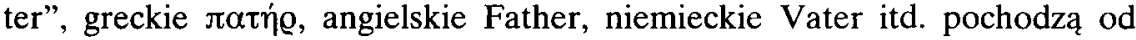
praindoeuropejskiego pierwiastka „PA”, który znaczy: żywić, bronić, chronić, dawać utrzymanie, protegować. Podstawowe zatem znaczenie „pater” to: żywiciel, dający dach nad głową, pracodawca, opiekun, obrońca i protektor. Dlatego ojcem nazywano również pana oraz opiekuna. Seneka pisze: „maiores nostri [...] dominum patrem familiae adpellaverunt $(E p .47,14)$. Slady takiego pierwotnego rozumienia funkcji ojca w rodzinie mamy już w królewskich ustawach, które nam przekazał Dionysius w Antiquitates Romanae II 15, 35-44.

Rozdział drugi zatytułowany: Bóg jako Ojciec w Konstytucjach Apostolskich (s. 63-102) rozpoczyna istotną część opracowania. Autor drogą analizy modlitw liturgicznych, zawartych w Konstytucjach, zgodnie z zasadą lex credendi est lex orandi, ukazuje ojcostwo Boga wobec Syna i względem ludzi: Ojciec kocha Syna, Syn jest posłuszny Ojcu, co odpowiada wzajemnemu odniesieniu 
między ojcem a pozostałymi członkami rodziny. Głównym darem Ojca wobec ludzi jest Syn, w którym następuje powrót człowieka do Stwórcy.

Kolejny, trzeci rozdział nosi tytuł: Ojciec rodziny w Konstytucjach Apostolskich (s. 103-144) i jest poświęcony analizie pozycji ojca rodziny tak, jak przedstawiają to Konstytucje. Człowiek jest kształtowany na wzór obrazu idealnego mężczyzny, jakim jest Chrystus. To On jest wzorcem w wychowaniu, stąd podstawową cechą jest pobożność pojęta jako poddanie Bogu i Jego prawu. Tak rozumiana pobożność ustawia relację ojca do innych ludzi, uczy szacunku, poszukuje woli Boga w odniesieniu do każdego. Ojciec nie tylko przekazuje życie fizyczne, ale przede wszystkim i nade wszystko kocha, czyli wychowuje, kształtuje w pobożności i prowadzi do świętości słowem i przykładem własnego życia.

Czwarty rozdział zatytułowany Reprezentant Boga Ojca (s. 145-174) ukazuje istotę ojcostwa biskupa uczestniczącego w ojcostwie Boga. Biskup nie podlega kontroli ze strony wspólnoty w zarządzie zebranymi darami, lecz odpowiada za nie przed Bogiem. Misja biskupa pochodzi bezpośrednio od Stwórcy, jego zadania spełniane we wspólnocie są mu zlecone przez Boga, którego jest zastępcą na ziemi.

W rozdziale piątym (s. 175-240) pt. Ojcowska posługa biskupa w Kościele, została ukazana ojcowska posługa biskupa. Zdaniem Autora dysertacji, wszystkie elementy posługi biskupiej, można umieścić w ramach zadań ojca względem rodziny. Poprzez posługę sakramentalną biskup rodzi we chrzcie do bycia dzieckiem Boga, natomiast w akcie święceń prezbiterów i diakonów, składa dziękczynienie wspólnoty „Ojcu, który jest w niebie”. Przez nauczanie będące wychowaniem, jak i kierowanie wspólnotą, biskup realizuje zadania ojca $d u$ chownego w rodzinie, jaką tworzą wszyscy wierzący w Chrystusa.

Rozdział szósty i ostatni (s. 241-264) pt. Kościót domem, stanowi podsumowanie książki. Autor zbiera kolejne elementy, by ukazać w syntetyczny sposób, że Kościół opisany w Konstytucjach Apostolskich jest przede wszystkim domem, a biskup pełni w tym domu rolę ojca.

W zakończeniu Autor dysertacji stawia tezę o konstytutywnej dla eklezjologii syryjskiej kategorii Kościoła jako domu. Obraz domu ma korzenie biblijne. Konstytucje Apostolskie świadczą, że w kręgu kultury semickiej jest on obecny aż do IV wieku. Autor przenosi się w czasy najnowsze wnioskując na podstawie doświadczenia ostatnich lat, że ten model Kościoła jest jakby wołaniem ludzi naszych czasów, zwłaszcza młodych. Wskazuje na fenomenem Jana Pawła II. Młodzi ludzie dostrzegli w nim ojca i poszli za nim. Zobaczyli ojca w miejsce Ojca, zobaczyli dom i przyszli do niego.

A zatem układ pracy jest jasny, dokładne podzielony, co rzuca się w oczy już przy spisie treści, a także stanowi ułatwienie dla czytelnika, bo staje się pomocne dla asymilacji bogactwa materiału, zawartego w rozprawie. Rzetelnie potraktował Autor stan badań. Uderza przejrzystość i jasność przekazu. 
Język pracy jest jasny i logiczny. Racjonalna treść jest komunikatywna. Autor swobodnie porusza się w źródłach i opracowaniach. Książka stanowi ważny wkład Autora w rozwój badań naukowych.

Ks. Augustyn Eckmann - Lublin, KUL

\begin{abstract}
Jerzy Andrzej WOJTCZAK-SZYSZKOWSKI, Fides et traditio. Wybór tekstów autorów wczesnego chrześcijaństwa (dla uczniów szkół katolickich, studentów i alumnów), Warszawa 2006, Drukarnia Archidiecezjalna w Katowicach, ss. 368.
\end{abstract}

Ktoś, kto przez ponad czterdzieści lat uczy nieprzerwanie języka łacińskiego, zawsze z radością patrzy na nowy podręcznik do nauczania mowy Rzymian przekształconej na język rzymskiego Kościoła. Dlatego drugi tom podręcznika pana profesora Wojtczaka-Szyszkowskiego (t. 1: Fides et litterae, Warszawa 1998, ss. 400; rec. H. Wójtowicz, VoxP 17:1997, t. 32-33, s. 500-503) przynoszący wybór tekstów wczesnochrześcijańskich wzbudził we mnie entuzjazm zupełnie szczególny, ponieważ zapewnia on rzeczywiste spotkanie $z$ najwcześniejszymi tekstami epoki chrześcijaństwa.

Autor - pisze w przedmowie - spełnił liczne życzenia czytelników, którzy po ukazaniu się tomu Fides et litterae prosili o podanie tekstów oryginalnych. W tym nowym zbiorze według założenia zestawiono teksty na zasadzie chronologii i ważności zagadnień, którym są poświęcone. Mają one być bowiem nie tylko środkiem do uczenia się języka, ale również ukazywać problematykę zainteresowań starożytnego Kościoła. Zbierający je Autor szukał takich fragmentów, w których znajduje się tematyka dogmatyczna, moralna, organizacyjna, pastoralna lub dyscyplinarna Kościoła okresu starożytności. Uwzględnia teksty łatwiejsze, z którymi student mógłby poradzić sobie o własnych siłach, i trudniejsze, wymagające pomocy i komentarzy ze strony nauczycieli. Zaznacza przy tym, ze w niektórych miejscach wprowadził pewne drobne uproszczenia składniowe.

Zgodnie z początkową zapowiedzią przedstawione teksty, dłuższe lub krótsze, są rzeczywiście bardzo różnorodne. Rozpoczyna je fragment pasji męczenników scyllitańskich uchodzącej za najstarszy łaciński tekst chrześcijański (180 r.), ale i przekazującej niezłomne wyznanie wiary „Christianus sum”, powtarzane w ciągu wielu wieków przez wszystkich, którzy oddawali życie za wiarę. Pogłębia to $\mathrm{w}$ najbliższym sąsiedztwie słynne wyznanie Tertuliana: „Plures efficimur, quoties metimur; semen est sanguis christianorum." Spośród pism sw. Cypriana znajdujemy teksty o jedności Kościoła, o radości w czasie przeSladowań (gaudere nos et exsultare voluit in persecutione Dominus), pojawiają się liczne fragmenty $z$ jego listów. Ireneusz dostarcza tekstów antyheretyckich, 